\title{
Aruba - a geochemical baseline study
}

\section{F. van den Oever ${ }^{1}$}

1 TAUW, Australiëlaan 5, P.O. Box 3015, 3502 GA UTRECHT, the Netherlands; e-mail: for@tauw.nl

Manuscript received: 15 September 2000; accepted in revised form: 9 June 2000

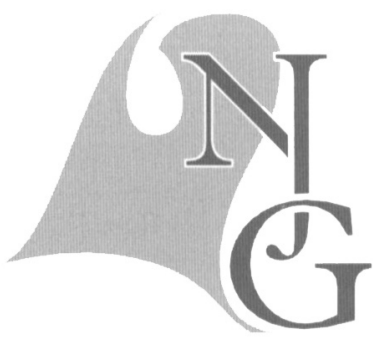

\begin{abstract}
A stream-sediment survey was carried out for the island of Aruba. Concentrations in stream sediments represent the abundance of chemical elements in the drainage basins. A geochemical atlas was created from the collected data and natural background values were established. Cluster analysis and pattern recognition techniques were used to gain a better understanding of the data set.

Two cluster models were selected to study the various geochemical controls on the sediments and to establish a spatial basis of environmental-quality settings for the development of future environmental policies. The first cluster model was suitable to recognise in some detail the reflection of the geology on the geochemistry of the stream sediments. The second, coarser cluster model stressed the importance to distinguish between the two main lithological units of the island when instituting natural background values. Not one uniform value per element is valid, but the value depends on the lithology.
\end{abstract}

Keywords: background values, environment, geochemical mapping, threshold values

\section{Introduction}

Geochemical mapping and other applications of surficial geochemistry are relevant to a wide variety of subjects, particularly because they can shed light on various problems concerning mineral exploration, geology, agriculture and environment. The results of geochemical mapping may reveal patterns that are directly related to the geochemistry of the bedrock. Also anomalies related to mineralization may be discovered. Superimposed on these patterns are, however, patterns related to human influences such as pollution resulting from waste dumps, agriculture and urbanisation. Due to the growing concern of the society about the (global) environment, and the increasing demand for new ore deposits, surficial geochemistry has become increasingly important.
In 1988, the International Geochemical Mapping Project (IGMP) was started. This project is organised by the International Geological Correlation Program under supervision of the IUGS/UNESCO. Its objective is to assess, demonstrate and recommend methods suitable for global geochemical mapping (Darnley, 1990; Darnley et al., 1995). Several countries have developed, or still are developing, geochemical maps (Webb, 1978; Steenfelt, 1987; Reid, 1993). It is in the spirit of this project that the geochemical investigation of Aruba was conducted, despite the fact that the area of investigation is far too small to be of interest for the IGMP. A stream-sediment survey was therefore conducted. Concentrations in stream sediments represent the abundance of chemical elements in the drainage basins.

Apart from creating a geochemical atlas, determin- 
ing the natural background values of the island was another objective. Geochemical baselines, or natural background concentrations of elements in the secondary environment, are needed for environmental legislation and political decision making.

The obtained dataset of the collected stream sediments was clustered with the fuzzy c-means clustering technique (FCM). The choice for the exact cluster model for further investigation was based, among other considerations, upon a pattern-recognition technique called non-linear mapping (NLM) and the geographical dispersion of the samples. Two cluster models were chosen for the twofold purpose of the present contribution. A 6-cluster model was used for further investigation of the geochemistry of the island and the geochemical maps, and a 2-cluster model provided support in setting quality objectives for soil.

\section{General characteristics of the island}

Aruba is the smallest and most western island of the Dutch Leeward Islands of the Lesser Antilles. The Lesser Antilles form the western part of the Aruba-La Blanquila chain, an E-W row of little islands and atolls on the Venezuelan continental borderland in the South of the Caribbean. Aruba is situated just north of the Venezuelan peninsula of Paraguana with its latitudes of $12^{\circ} 25^{\prime}-12^{\circ} 36^{\prime} 30^{\prime \prime}$ and longitudes $69^{\circ} 52^{\prime}$ $70^{\circ} 04^{\prime}$. Aruba is not, contrary to Bonaire and $\mathrm{Cu}-$ raçao, separated from the Venezuelan continent by the Bonaire Basin but is part of the Venezuelan continental flat. The distance between Aruba and the Venezuelan peninsula Paraguana is about $35 \mathrm{~km}$ and the maximum water depth in between is not more than 190 $\mathrm{m}$. The island is $31 \mathrm{~km}$ long and $9 \mathrm{~km}$ wide and its surface area is about $190 \mathrm{~km}^{2}$. The main axis of the island has a NW-SE direction.

The semi-arid climate is largely characterized by an annual rainfall varying between 3.4 and $6.8 \mathrm{~m}$ and a mean annual temperature of $27^{\circ} \mathrm{C}$. Most of the rain falls from the end of October to January. The natural vegetation consists of scrub-bushes, divi-divi trees and xerophytes.

Aruba is almost continuously exposed to the trade winds blowing from easterly directions. Due to these trade winds and the high temperature, the potential evaporation is about $10 \mathrm{~mm} /$ day on open water. There is generally little soil cover because of the combination of climate, trade winds, seasonal rain and scarce vegetation. The soils contain a high percentage of gravel, and are often shallow, except for some pockets of deeper alluvium. Most of the erosion products get washed or blown away by the trade winds and the seasonally occurring rain.

\section{Geological setting}

Aruba is made up of a core of folded metamorphosed sedimentary and igneous rocks of Cretaceous age, unconformably overlain by (possibly) Eocene, Neogene and Quaternary limestone deposits (Westermann, 1932; De Buisonjé, 1974; Beets \& MacGillavry, 1977; Herweijer \& Focke, 1978). The geological setting consists of three major lithological units (Fig. 1): the Aruba Lava Formation, a tonalitegabbro batholite, and Neogene and Quaternary limestones. In the past four hundred years, gold has been mined on the island. Elevated gold values have been reported for some 200 quartz veins.

\section{The Aruba Lava Formation}

The Aruba Lava Formation (ALF) is the oldest unit exposed. It occurs mainly in the central and northeastern part of the island, in a hilly landscape in which the highest points of the island are situated like the Yamanota $(188 \mathrm{~m})$ and Arikok $(185 \mathrm{~m})$. The ALF is cut off at the north-eastern part by the Caribbean Sea and on the other sides by the composite batholite, which intruded the ALF. The ALF is a $3 \mathrm{~km}$ thick succession of basalts, dolerites, pyroclastics, volcan-

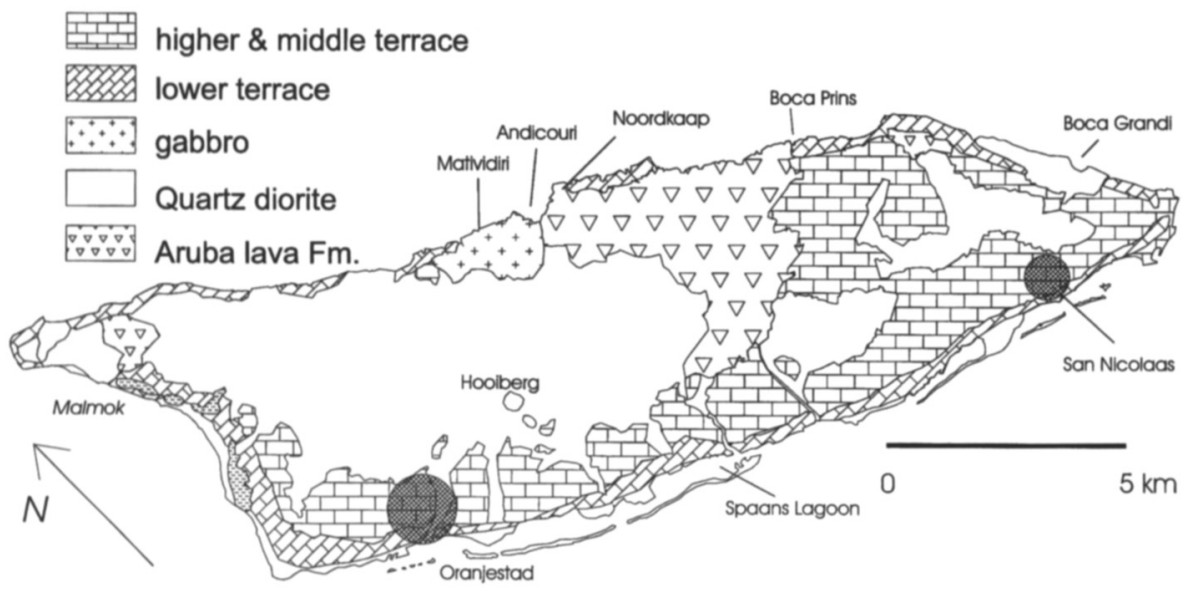

Fig. 1. Simplified geological map of Aruba. 
oclastics, phyllites, hornblende schists and amphibolites. The major components, basalts (occurring as pillow lavas) and dolerites, are all of a saturated to slightly undersaturated basaltic composition (Monen, 1980). The major part of the ALF has been metamorphosed by the intrusion of the tonalite gabbro batholite. At the contact, the rocks are metamorphosed to a hornblende-hornfels facies. The major part of the rocks have an albite-epidote-hornfels/greenschist characteristic (Westermann, 1932; Monen, 1980).

Major and trace element data show that the volcanites belong to the MORB (Mid-Oceanic Ridge Basalts) (Monen, 1980; Donnelly \& Rogers, 1987). The age was estimated by Beets \& MacGillavry (1977) to be Turonian (Late Cretaceous) on the basis of ammonites found in the sediments of the ALF succession.

\section{The tonalite-gabbro batholite}

The tonalite-gabbro batholite covers the main part of the island. It is a Turonian composite tonalite-gabbro batholite of mainly tonalitic (quartz-dioritic) composition (Priem et al., 1986). A wide variety of rock differentiates such as tonalite, gabbro, quartz-norite, hooibergite, magmatic breccias, trondjemite and pegmatite veins can be distinguished (Westermann, 1932; Monen, 1980). On the whole, the batholite occurs in a weathered phase, especially the tonalite (the tonalite will in the following be abbreviated as quartz-diorite $=\mathrm{QD}$ ). The rocks crop out over large distances as heaps of big, roundish and exfoliated monoliths, which lie in plains of diorite detritus. The QD consists mainly of medium- to large-grained quartz, feldspar, biotite and hornblende. Widespread assimilation of country rock (basalts, diorites, etc.) has taken place by the intrusive magma.

The gabbros and quartz-norites, which are more resistant to erosion, are exposed in the Matividiri area and its surrounding hills. They are dark coloured and medium-grained rocks. The steep hooibergite hills are encountered in several places in the diorite landscape, which is in general relatively flat. Because of their relative high resistance to erosion, they clearly 'pop out' of the landscape. The hooibergites (melatonalites), which are dark coloured rocks with particularly large hornblende crystals, are intermixed with trondjemitepegmatite veins. Narrow, discontinuous mylonite zones and large inclusions of hornblende gneiss also occur in the hooibergites (Westermann, 1932; Helmers, 1977; Helmers \& Beets, 1977).

\section{Neogene and Quaternary limestones}

This part of the geological history was characterised by the deposition of shallow-marine limestones. The limestones can be divided into three groups:

- the Seroe Domi Formation, which ranges from Neogene to Quarternary age and consists of coral debris and erosional products from older formations;

- the terraces, which are of Quarternary age and were distinguished by De Buisonjé (1974) in three levels: the Lower Terrace Limestone, the Middle Terrace Limestone and the Higher Terrace Limestone; their genesis took place during periods of rising and falling sea levels (Herweijer \& Focke, 1978, and they are partly erosional surfaces of the older Seroe Domi Formation and partly accumulation terraces of coral debris;

- the eolianites, which are little, gently rolling hills, consisting of undulating windblown limesands.

\section{Sampling and analysis}

\section{Sampling and sample preparation}

During the dry season in 1991 (all stream beds were dry), 92 stream sediments consisting of stream-bed and stream-bank material were collected at 1-5 sites within a $25 \mathrm{~m}$ section of the stream. This results in an average sample density of 1 sample per $2 \mathrm{~km}^{2}$. Attempts have been made to quantify the effect of dilution of a dispersion train and thereby provide a sound basis for establishing sample spacing and as an aid in interpretation (Hawkes, 1976). Establishing an optimum sampling density depends on several factors like relief, catchment area and shape of the drainage basin, and obviously also of the aim of the investigation. Figure 2 gives the sample locations and the dry river beds (local name: 'rooi').

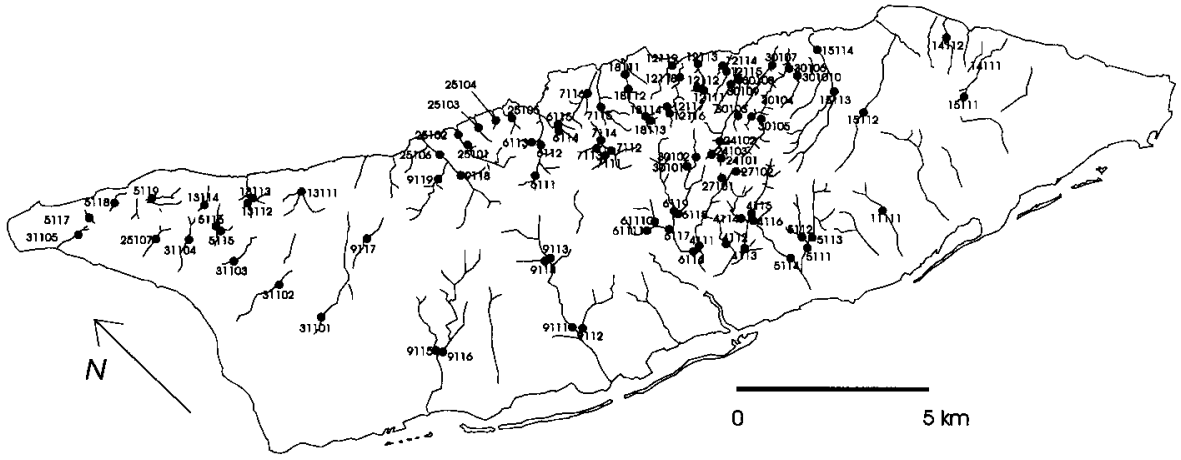

Fig. 2. Sample location map of the stream sediments. 
The ALF has a relative high sampling density. The sample density in the limestones, however, is low. Out of 92 samples, 39 were taken in the ALF, 7 samples in the gabbro, and 6 samples in the limestone; the remaining 40 samples were taken in the QD. Apart from the limestones, the different geological units have thus an adequate sample density.

A study by Beeson (1984) showed that, for similar terrain and circumstances in Australia, a significant difference existed in using several fine fractions of stream sediments for chemical analysis. A small pilot study on the Aruba samples, comparing $<212,<125$, $<106,<63$ and $<53 \mu \mathrm{m}$ fractions showed no important differences or enhanced anomaly/background contrast. All of the samples were first split and then sieved to a grain size of $<125 \mu \mathrm{m}$ (120 mesh).

\section{Chemical analysis}

It was not necessary in the framework of the present study to determine the total concentration of elements in the samples. Partial dissolution, such as aqua-regia leach, was therefore chosen: it allows the determination of element concentrations in economically or environmentally significant phases, while avoiding the incorporation of data from refractory minerals that might distort or hide trends in the elements of interest (Jarvis \& Jarvis, 1992).

Of each sample $0.25 \mathrm{~g}$ of sieved matter was leached with aqua regia $\left(1 \mathrm{HNO}_{3}: 3 \mathrm{HCL}\right)$ for several hours at $90^{\circ} \mathrm{C}$ and, after cooling, diluted to $50 \mathrm{ml}$ with demineralised water. These solutions were analysed by ICP-AES (Inductively Coupled Plasma - Atomic Emission Spectrometry), ARC-34000, 30-channel-simultaneous, for the major and some trace elements (Al, Ba, $\mathrm{Ca}, \mathrm{Co}, \mathrm{Cr}, \mathrm{Cu}, \mathrm{Fe}, \mathrm{K}, \mathrm{Li}, \mathrm{Mg}, \mathrm{Mn}, \mathrm{Na}, \mathrm{Ni}$, $\mathrm{P}, \mathrm{S}, \mathrm{Sr}, \mathrm{Ti}, \mathrm{V}, \mathrm{Y}, \mathrm{Zn}, \mathrm{Zr}$ ).

\section{Quality control}

Several field-sample and laboratory duplicates were analysed to monitor the precision of the chemical analysis. International reference samples were simultaneously analysed in these series for an appraisal of the accuracy of the method. The results of the duplicate and international reference samples showed an overall good precision and accuracy of the sample preparation and analysis. The data for $\mathrm{Pb}$, however, were mostly below the detection limit, and were deleted from the data set.

\section{Statistical treatment of the data}

To gain a basic insight in the data set, histograms were made and some basic statistical parameters were calculated (Table 1). All element distributions have a log-normal character. Log-transformed data were therefore used throughout the data treatment.

Numerous studies have been written concerning the treatment of geochemical data. There are as many pitfalls as there are different techniques and approaches. Blindly applying techniques can have the same effect as the proverbial 'bull in a china shop'. One has to assess the different approaches with each its own advantages and disadvantages, finally coming to a satisfactory manner of treating the data (Howarth, 1984; Chork \& Govett, 1985; Plant et al., 1988; Kürzl, 1988; O’Conner \& Reimann, 1993).

There are also various ways to visualise geochemical data on maps. Dots (with dot size related to content), different symbols, colour images and shaded relief are some of the possibilities, with each its own disadvantages and advantages (Björklund \& Gustavsson, 1987). Because the data set was relatively small, it was sufficient to attribute the elements in five groupings based on the histograms of the log-transformed data, and to give each grouping a dot size related to contents. The maximum size of the dots must be related to the data density and small dots covered by large dots can become a problem with uneven sample density. To avoid these problems, open circles where used. The distribution of a number of elements are displayed in Figure 3. The complete set of maps (the geochemical atlas) is found in Van den Oever (1993).

\section{Fuzzy c-means clustering and non-linear mapping}

Many classical multivariate statistical procedures require population homogeneity. Because of the inhomogeneous data set (and not knowing the classificatory parameter), and because the various unknown geochemical controls on the samples were sought, cluster analysis and pattern recognition are appropriate techniques for interpretation of the dataset (Davis, 1986). Adequate understanding of the dataset can be provided by the groupings obtained by such analysis. Trying to classify objects of different characteristics into different categories can, however, be troublesome. Boundaries among objects of different categories are sometimes ambiguous, thus causing misclassification of geochemically similar members into entirely different clusters. Various degrees of overlap are encountered because naturally occurring materials are often not well separated in homogeneous groupings, for instance, in mixed samples ( $\mathrm{Yu} \& \mathrm{Xie}$, 1985; Vriend et al., 1988). Fuzzy c-means (FCM) clustering may give a better performance. Vriend et al. (1988) showed that a combination of FCM and 
Table 1. Basic statistics for the Aruba stream-sediment data set.

$\mathrm{x}$ is the arithmetic mean; $\mathrm{b}$ is the geometric mean; $\mathrm{x}-\mathrm{s}$ and $\mathrm{x}+\mathrm{s}$ are the estimates of the $68 \%$ interval in case no transformation is applied; $\mathrm{b}-\mathrm{s}$, and $b+s_{1}$ are the $68 \%$ interval estimate based on the logarithmic transformation of the data. Outliers were removed prior to the calculation of the basic statistics. $\mathrm{Al}, \mathrm{Fe}, \mathrm{Ca}, \mathrm{Mg}, \mathrm{Na}$, and $\mathrm{K}$ are given in mass \%, and the other elements in ppm.

\begin{tabular}{|c|c|c|c|c|c|c|c|c|c|}
\hline & $\mathrm{x}$ & $\mathrm{b}$ & $\min$ & $\max$ & $\mathrm{x}-\mathrm{s}$ & $x+s$ & $b-s_{1}$ & $\mathrm{~b}+\mathrm{s}_{1}$ & $\mathrm{n}$ \\
\hline \multicolumn{10}{|c|}{ Major elements } \\
\hline $\mathrm{Al}$ & 3.14 & 2.95 & 1.33 & 5.84 & 2.08 & 4.21 & 2.06 & 4.24 & 92 \\
\hline $\mathrm{Fe}$ & 4.65 & 4.38 & 1.31 & 11.21 & 3.04 & 6.26 & 3.06 & 6.27 & 92 \\
\hline $\mathrm{Ca}$ & 2.02 & 1.69 & 5.81 & 1.06 & 0.36 & 3.68 & 0.98 & 2.90 & 92 \\
\hline $\mathrm{Mg}$ & 1.34 & 1.14 & 0.21 & 3.70 & 0.59 & 2.09 & 0.62 & 2.08 & 92 \\
\hline $\mathrm{Na}$ & 0.20 & 0.16 & 0.07 & 1.22 & $<0$ & 0.43 & 0.08 & 0.30 & 92 \\
\hline $\mathrm{K}$ & 0.29 & 0.27 & 0.12 & 0.62 & 0.18 & 0.40 & 0.18 & 0.40 & 92 \\
\hline \multicolumn{10}{|c|}{ Minor elements } \\
\hline $\mathrm{Ba}$ & 70 & 50 & 20 & 300 & 20 & 120 & 30 & 110 & 92 \\
\hline $\mathrm{Co}$ & 20 & 20 & 5 & 60 & 10 & 40 & 10 & 40 & 92 \\
\hline $\mathrm{Cr}$ & 140 & 90 & 10 & 590 & 25 & 250 & 40 & 240 & 92 \\
\hline $\mathrm{Cu}$ & 90 & 70 & 10 & 190 & 45 & 130 & 40 & 135 & 92 \\
\hline $\mathrm{Li}$ & 10 & 10 & 1 & 30 & 3 & 15 & 5 & 10 & 92 \\
\hline $\mathrm{Mn}$ & 740 & 700 & 580 & 1560 & 470 & 1010 & 480 & 1000 & 92 \\
\hline $\mathrm{Ni}$ & 50 & 30 & 6 & 190 & 10 & 90 & 15 & 80 & 92 \\
\hline $\mathrm{P}$ & 400 & 340 & 90 & 1000 & 180 & 620 & 190 & 610 & 92 \\
\hline$S$ & 300 & 170 & 40 & 3050 & $<0$ & 740 & 75 & 390 & 92 \\
\hline Sr & 100 & 80 & 30 & 200 & 60 & 110 & 60 & 110 & 91 \\
\hline $\mathrm{Ti}$ & 2400 & 2280 & 520 & 5070 & 1610 & 3260 & 1540 & 3370 & 92 \\
\hline $\mathrm{V}$ & 180 & 170 & 35 & 590 & 100 & 260 & 110 & 250 & 91 \\
\hline$Y$ & 10 & 10 & 5 & 20 & 10 & 10 & 10 & 10 & 92 \\
\hline $\mathrm{Zn}$ & 50 & 50 & 15 & 100 & 30 & 70 & 30 & 70 & 91 \\
\hline $\mathrm{Zr}$ & 3 & 3 & 1 & 10 & 1 & 5 & 1 & 5 & 92 \\
\hline
\end{tabular}

non-linear mapping (NLM) perform well in such cases. FCM differs from other conventional clustering techniques by the fact that some 'fuzziness' or vagueness is allowed (Bezdek et al., 1984). Interest is not in whether chances are largest that a case belongs entirely to one specific cluster, but in the similarity between case and cluster and how much they are alike. FCM determines a so-called 'membership' or similarity for each sample in each cluster. Memberships have a value between 0 (not belonging to the cluster) and 1 (equal to the cluster centre). The sum of each membership of a sample equals exactly 1 . By means of the exponent, $\mathrm{q}$, one can regulate the fuzziness or measure of vagueness of the cluster analysis. This exponent discriminates samples that are situated further away from the cluster centre, thus weighing less and having less influence on the computation of the final cluster model. A value of 1.5 for the exponent, $\mathrm{q}$, gives commonly satisfactory results (Vriend et al., 1988). Outliers can easily be detected because they have more or less equal memberships for each cluster. Mixed samples share memberships for several clusters.

FCM has been successfully applied on datasets in various fields. Geochemistry and geology are suitable fields. They have commonly heterogeneous multivariate data sets and not all parameters of interest are known a priori (Xu \& Yie, 1985; Vriend et al., 1988; Frapporti et al., 1993). For some applications, fuzzy clusters are transformed into 'ordinary' hard or crisp clusters by rounding the membership values to the integers, 0 and 1.

NLM is a pattern-recognition technique, independent of FCM, which plots the dataset in a 2-dimensional plane. The distances in the multi-dimensional data cloud are determined in such a way that the interdata distances are minimally distorted when projected in a 2-D plane. These distances are therefore projected in a more realistic way than simple projection planes obtained by principal-component analysis. Samples that resemble each other chemically are therefore plotted closer to each other than non-resembling samples.

Both FCM and NLM were applied successfully on the obtained analytical results. The results are discussed in the next chapter.

\section{Results}

Figure 3 reveals that the base metals such as $\mathrm{Zn}$ increase in concentration following the geology from the QD through the Matividiri gabbro to the ALF. The QD is a rather depleted intermediately acid intrusive batholite. The gabbro, also belonging to the 

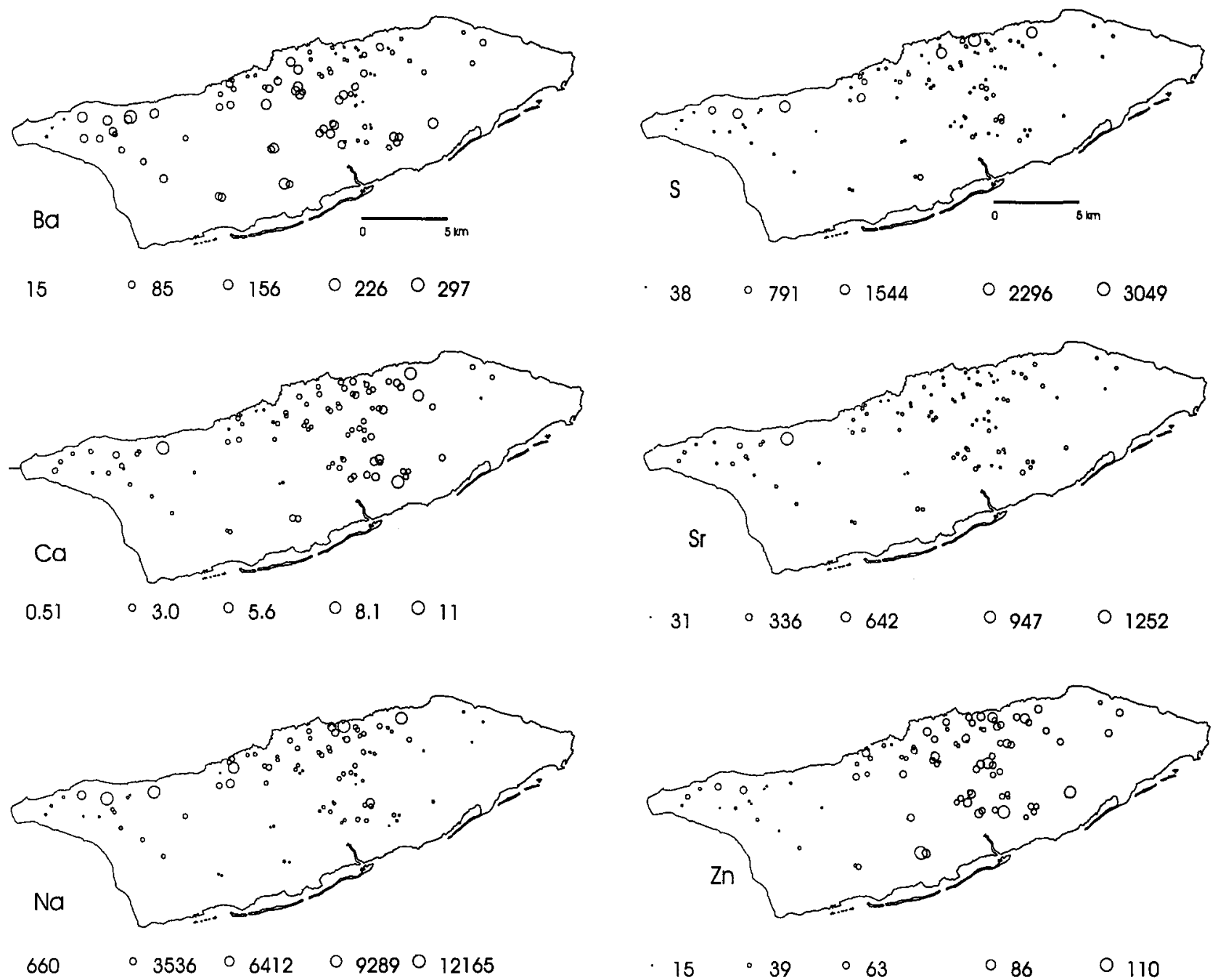

Fig. 3. Examples of the spatial distribution of element concentrations in the stream sediments.

batholite, is generally more enriched in element concentration (e.g., mainly metals), and the ALF contains the highest values for most of the elements. There are a few exceptions, however.

$\mathrm{Ba}$ en $\mathrm{Sr}$ are lithophile trace elements relatively enriched in the QD. The intermediately acid QD contains no first crystallisation minerals, thus being relatively enriched in plagioclase. Ba can readily substitute $\mathrm{K}$ in $\mathrm{K}$-feldspar, and $\mathrm{Sr}$ may substitute $\mathrm{Ca}$ in plagioclase (Wilson, 1989). This explains the enrichment of $\mathrm{Ba}$ and $\mathrm{Sr}$ in the QD. Sr can also replace $\mathrm{Ca}$ in carbonates in limestones (Broecker \& Peng, 1982). Na and $S$ have higher values on the north side of the island, regardless of geology. This can be explained by the fact that the trade winds, constantly blowing from the east, carry some sea spray containing $\mathrm{Na}$ and sulphate to the shore.

A few samples were undoubtedly reflecting human influences. Most of the inhabitants live on the southwestern and southern part of the island and are most likely influencing the samples taken on this side. Because of the urbanisation around, and between, Oran- jestad and Sint Nicolaas, it is difficult to collect samples that reflect only geology. Future investigations could concentrate more on this part of the island. For example, sample 9111 has an unnatural high $\mathrm{Zn}$ content of almost $800 \mathrm{ppm}$. Sample 13111 is a composite sample taken in a salina that glittered with little salt crystals, thus having a high $\mathrm{Na}$ and $\mathrm{S}$ content. It has also a high $\mathrm{Ca}$ concentration.

The geochemistry of the limestones is not clearly identified. Too few samples were taken in the limestones. The limestones appear to be in a very leached, weathered phase. Moreover, the roois in which the samples were taken, cut through the limestones onto the underlying geology (QD, ALF). More specifically collected samples could enhance the geochemical print of the limestones (if present at all).

\section{The clusters}

When the results of the FCM clustering (ranging from a 2-cluster model to a 8-cluster model) were plotted by the NLM technique, each cluster model showed consistency in partitioning. All the groupings form a differ- 
ent cluster. The 6-cluster model is used to gain a deeper insight into the geology and geochemistry of the island. The 2-5 cluster models were rejected, because they didn't reveal as much information as the 6-cluster model. This was mainly due to their coarser classification. The 7-cluster and 8-cluster models were rejected because they contained clusters with too few samples to be significant. The results of the 6-model cluster are discussed below. Figure 4 is a NLM plot of the FCM results of the 6-cluster model and Figure 5 gives the geographical distribution of the clusters. The cluster centres created by FCM are listed in Table 2 .

The Streckeisen diagram (Cox et al., 1979) shows that no major differences concerning quartz/alkali-feldspars/plagioclase/feldspatoids compositions are present. The QD and gabbro (plutonic) and the basalts (volcanic) plot on the same corner. The QD has a higher $\mathrm{SiO}_{2}$ content. Table 3 lists some averaged results of analyses of the ALF, made by Monen (1980).

From a geographical point of view (Fig. 5), clusters 1,2 and 4 belong to the QD. Cluster 3 is mainly situated in the Matividiri gabbro (with a few exceptions). Clusters 5 and 6 are situated in the ALF. The differences between the clusters can be explained by taking into account the geographical positions of the clusters, the chemical distribution, the geology, comparison to rock analyses of the ALF, and some average element compositions of igneous rocks (Cox et al., 1979).

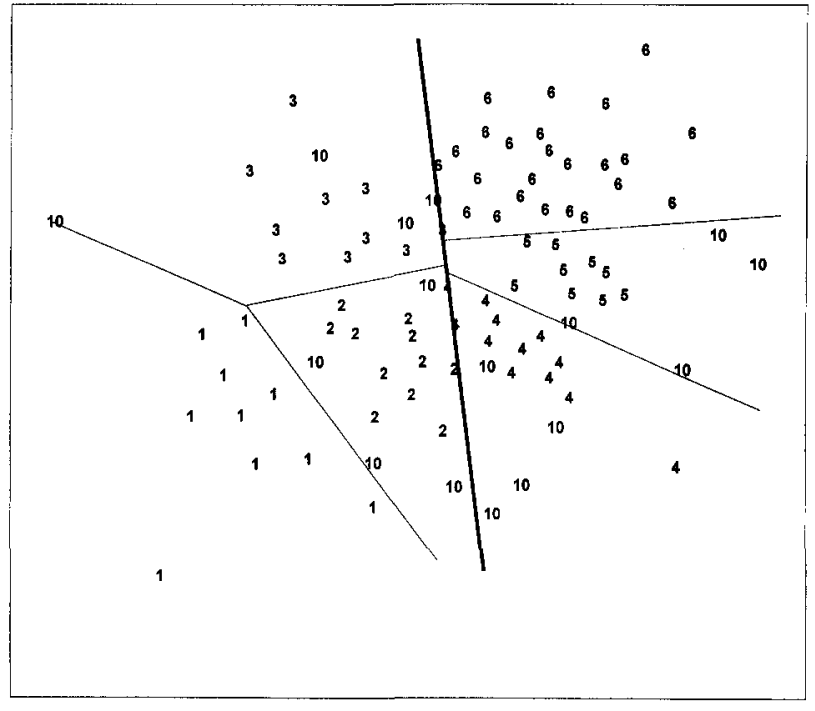

Fig. 4. NLM plot of the 6-cluster model.

\section{Acidic QD cluster (cluster 1)}

The acidic QD cluster samples are found only in the western part of the island, which is also the lowest part. The geological setting is the QD. It contains the lowest element concentrations, except for $\mathrm{Ba}$ and $\mathrm{Sr}$. On this part of the island, the QD is the most depleted in element concentration. This part of the batholite represents a less basic (subsilicic) part.

Table 2. Cluster centres for a 6-cluster model. $\mathrm{Al}, \mathrm{Fe}, \mathrm{Ca}, \mathrm{Mg}, \mathrm{Na}$, and $\mathrm{K}$ are given in mass \%, and the other elements in ppm.

\begin{tabular}{|c|c|c|c|c|c|c|}
\hline & acidic QD & interm. QD & basic QD & gabbroic & volcanic & intrusive \\
\hline \multicolumn{7}{|c|}{ major elements } \\
\hline $\mathrm{Al}$ & 1.86 & 2.37 & 2.20 & 3.15 & 3.54 & 4.14 \\
\hline $\mathrm{Fe}$ & 2.44 & 3.71 & 5.29 & 4.32 & 5.19 & 5.37 \\
\hline $\mathrm{Ca}$ & 1.08 & 1.45 & 1.17 & 1.84 & 1.91 & 2.26 \\
\hline $\mathrm{Mg}$ & 0.42 & 0.90 & 0.84 & 1.12 & 1.67 & 2.03 \\
\hline $\mathrm{Na}$ & 0.10 & 0.14 & 0.14 & 0.14 & 0.19 & 0.20 \\
\hline $\mathrm{K}$ & 0.16 & 0.26 & 0.23 & 0.35 & 0.35 & 0.26 \\
\hline \multicolumn{7}{|c|}{ minor elements } \\
\hline $\mathrm{Ba}$ & 85 & 81 & 39 & 95 & 60 & 26 \\
\hline Co & 8 & 15 & 19 & 19 & 29 & 38 \\
\hline $\mathrm{Cr}$ & 25 & 58 & 124 & 56 & 157 & 228 \\
\hline $\mathrm{Cu}$ & 28 & 59 & 63 & 80 & 119 & 116 \\
\hline $\mathrm{Li}$ & 3 & 6 & 7 & 9 & 9 & 9 \\
\hline $\mathrm{Mn}$ & 445 & 540 & 595 & 690 & 835 & 1025 \\
\hline $\mathrm{Ni}$ & 11 & 19 & 29 & 26 & 56 & 89 \\
\hline $\mathrm{P}$ & 192 & 445 & 269 & 497 & 457 & 261 \\
\hline$S$ & 116 & 145 & 119 & 185 & 189 & 206 \\
\hline $\mathrm{Sr}$ & 78 & 89 & 76 & 106 & 81 & 73 \\
\hline $\mathrm{Ti}$ & 1690 & 1900 & 2150 & 2150 & 2800 & 2950 \\
\hline V & 93 & 145 & 225 & 160 & 200 & 203 \\
\hline $\mathrm{Y}$ & 7 & 8 & 7 & 10 & 11 & 13 \\
\hline $\mathrm{Zn}$ & 23 & 45 & 35 & 65 & 60 & 56 \\
\hline $\mathrm{Zr}$ & 2 & 2 & 2 & 2 & 3 & 5 \\
\hline
\end{tabular}


Table 3. Averaged results of some rock types based on the results of Monen (1980). $\mathrm{Al}, \mathrm{Fe}, \mathrm{Ca}, \mathrm{Mg}, \mathrm{Na}$, and $\mathrm{K}$ are given in mass \%, and the other elements in ppm.

\begin{tabular}{lccc}
\hline & gabbro & basalts & dolerites \\
\hline major elements & & & \\
$\mathrm{Al}$ & 7.82 & 7.78 & 7.72 \\
$\mathrm{Fe}$ & 6.78 & 8.24 & 7.32 \\
$\mathrm{Ca}$ & 6.16 & 7.98 & 9.15 \\
$\mathrm{Mg}$ & 4.04 & 4.94 & 5.22 \\
$\mathrm{Na}$ & 2.51 & 2.03 & 1.54 \\
$\mathrm{~K}$ & 0.51 & 0.16 & 0.10 \\
& & & \\
minor elements & & & \\
$\mathrm{Co}$ & 30 & 50 & 40 \\
$\mathrm{Cr}$ & 160 & 250 & 330 \\
$\mathrm{Mn}$ & 1200 & 1380 & 1240 \\
$\mathrm{Ni}$ & 40 & 90 & 130 \\
$\mathrm{P}$ & 610 & 430 & 300 \\
$\mathrm{Sr}$ & 320 & 120 & 80 \\
$\mathrm{Ti}$ & 4450 & 6340 & 5620 \\
$\mathrm{Zn}$ & 60 & 80 & 50 \\
$\mathrm{Zr}$ & 50 & 70 & 60 \\
& & & \\
\hline
\end{tabular}

Intermediate $Q D$ cluster (cluster 2)

The samples from the intermediate QD cluster are mainly situated near the QD-ALF contact, except for samples 31103,30103 and the mixed samples 5116 (cl2-1), 31101 (cl2-3), 7115 (cl2-4) and 25106 (cl23). The QD/ALF contact is at a somewhat higher elevation than the acidic $Q D$ cluster samples. Only the samples 30103 and $7115(\mathrm{cl} 2-4)$ are situated in the ALF, all the rest in the QD. The element distributions indicate that there are no major chemical differences between the intermediate and acidic cluster, except for the fact that the former cluster has a somewhat higher content of element concentrations. It can thus be concluded that the intermediate $\mathrm{QD}$ cluster also represents the QD, but a little more enriched part of the QD (more basic).

\section{Gabbroic cluster (cluster 3)}

Four samples are situated in the Matividiri gabbro, 3 samples $(31105,5117,5118)$ in the little ALF outcrop in the north-western part of the island, one in the middle of the QD (9117), and samples 12112 and 6115 in the ALF. The geographical distribution already gives an indication that the gabbroic cluster might represent the gabbro. Other cluster models give also a specific cluster for these sample sites (including the three samples situated near the ALF outcrop in the north-eastern part of the island).

The cluster- 3 chemistry is clearly different from the other clusters. It has higher contents in $\mathrm{Fe}, \mathrm{Cr}, \mathrm{Ni}, \mathrm{V}$, $\mathrm{Zr}$ and $\mathrm{Ti}$, and lower contents in $\mathrm{Ca}, \mathrm{P}, \mathrm{Ba}, \mathrm{Y}, \mathrm{Zn}$. The higher content of $\mathrm{Fe}, \mathrm{Cr}$, Ni indicates the presence of the main ferro-magnesian pyroxene minerals of gabbros, norites, dolerites and basalts (Deer et al., 1992). $\mathrm{Zr}$ is a major element of the mineral zircon (zircon is a common accessory mineral in igneous rocks). The higher content of $\mathrm{Ti}$ and $\mathrm{V}$ could be explained by the appearance of ilmenite and rutile in the gabbro; both are also common accessory minerals in igneous rocks. These accessory minerals are, however, very resistant to weathering. Aqua-regia leach prior to analyses by ICP-AES is not such a strong dissolution that resistant minerals like rutile and zircon are easily dissolved (Chao \& Sanzaolone, 1992). It is more likely that the rise in trace-element concentration comes from dissolution of pyroxene, biotite, hornblende, micas and, particularly, secondary minerals (e.g., clay minerals; Al, Fe-hydroxides).

It still remains peculiar that three samples (31103, $5117,5118)$ are situated in or near the little ALF outcrop in the north-western part. Taking a closer look at this ALF outcrop might be an interesting topic for future geological investigations.

\section{Basic QD cluster (cluster 4)}

This cluster is also situated in the QD. Most of the samples are near the QD/ALF contact, just like the intermediate $\mathrm{QD}$ cluster. They sometimes share the same rooi systems. Samples 5111, 5112, 11111 and 14111 were collected in the south-eastern part of the island. The basic QD cluster has a slightly higher element concentration than the acid QD cluster. One

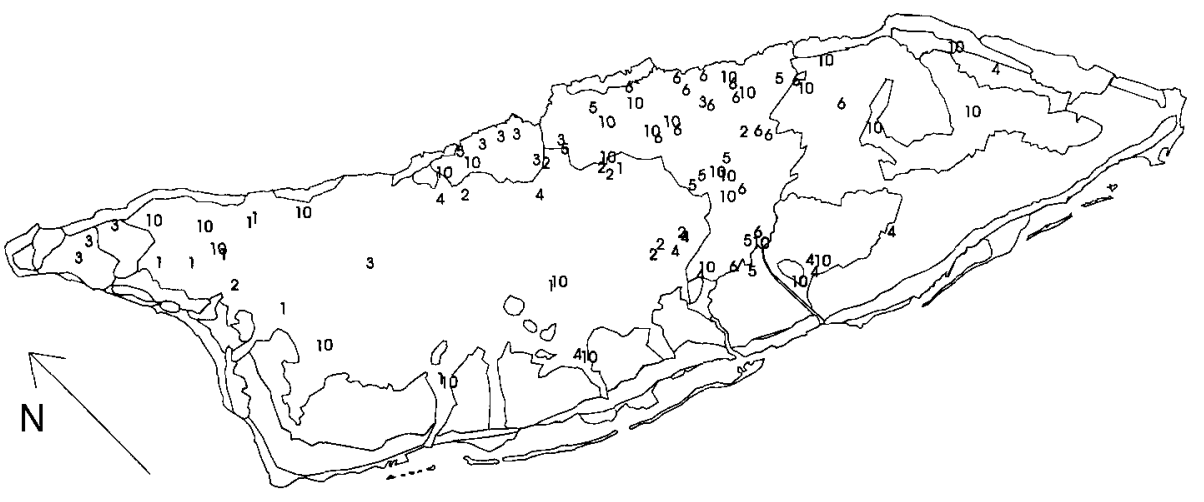

Fig. 5. Geographical distribution of the clusters of the 6 -cluster model. 
has to be careful not to interpret the basic QD cluster as the intermediate QD cluster with some influences from the ALF. A closer look at the rooi courses shows that only few roois have their origin in the ALF.

\section{Volcanic ALF cluster (cluster 5)}

This cluster consists of nine samples and one mixed sample (24103 cl5-6). Except for one (25102), all the volcanic ALF cluster samples are situated in the ALF. The ALF consists mainly of basalts, tuffs and dolerites (Monen, 1980). All element concentrations rise except for $\mathrm{K}, \mathrm{Ba}, \mathrm{Sr}, \mathrm{P}$ (mobile elements). The presence of pyroxines, amphiboles, hornblende, chlorite, epidote can account for the higher content compared to the QD.

The geological map of the ALF, created by Monen (1980) was used to pinpoint exactly in what subsetting of the ALF the samples were taken. All samples, except 25102, were collected in roois in the basalts or tuffs. It was concluded, by comparing the volcanic ALF cluster and the intrusive ALF cluster and averaged compositions of ALF samples collected by Monen (1980) and some average major element compositions of common igneous rock types (Cox et al., 1979), that cluster 5 represents the basalts and tuffs in the ALF.

\section{Intrusive ALF cluster (cluster 6)}

This cluster is also situated in the ALF, except for two samples (15113, mixed $301010 \mathrm{cl} 2-5)$ collected in the QD just east of the ALF. This cluster exists of sixteen samples and six mixed samples. Sixteen of the samples were collected in roois that originate or run through dolerite sills (intrusive dikes and sills). Most element concentrations are (slightly) higher than in cluster 5, except for K, P, Ba and Sr (again the mobile elements). Cluster 6 represents the dolerites in the ALF.

Natural background values of some environmentally important metals

Due to the growing social concern about the environment, numerous reports have been written to provide scientific support for the establishment of sound environmental policies. Environmental-quality objectives for water, sediment and soil have to be set. Several scientific disciplines, such as geology, hydrology, chemistry, biochemistry, eco-toxicology and agricultural sciences, produce numerous reports concerning this subject.

Analytical results must be carefully assessed to see if they represent natural background values or reflect some Man-made pollution. In the scope of the pre- sent study, only baseline or natural background values are of interest. It is obvious that one cannot simply project the framework of Dutch reference values onto Aruba, because of the totally different parameters involved. The Netherlands is covered with various soil types with different parameter values. Because equilibrium models for heavy metals must account for quite a large number of factors that control the adsorption and desorption of metals in soils, it is difficult to establish general reference values.

In (contaminated) soils, heavy metals occur incorporated in, and absorbed to, clay minerals and Al-Fe(hydr)oxides, as organo-metallic compounds built-in in minerals, as ions dissolved in water, and occasionally even in elemental form. Each soil (type) has its own contents of clay fraction (lutum, particles $<2$ $\mu \mathrm{m})$ and organic content (humus), which both are often related to the metal content. The possibility that unwanted side effects occur, arising from the presence of these elements, is not only dependent on their total concentration, but also on the soil composition, $\mathrm{pH}$ and redox potential. The $\mathrm{pH}$ and redox potential are, because of their variability in time, considered less useful for establishing reference values. The probability that negative side effects occur depends on the relation between the concentration of elements and the sorption capacity of the soil, the latter being determined by lutum and organic content.

Basically there are two approaches to determine reference values for soils. The first approach involves the definition of homogeneous soil types; within each soil type a unique set of reference values is operative. If the number of soil types is large, this method may, however, be rather cumbersome. In the second approach, a gliding scale is defined based on one or more independent soil features. It has the advantage that it is often relatively straightforward and simple to use.

The combining factors geology, relief, type and degree of vegetational overgrowth, and most importantly, climate determine on Aruba the sort and degree of weathering. All these factors cause the weathering to be mainly physical. The weathering detritus is relatively unaltered, because there is little water available for chemical alteration of the primary minerals into secondary (clay). Soil formation for commercial cultivation is virtually absent. Only at Fontein, in the north-east of the island, vegetables are grown and at Paradijs; north of Oranjestad, plants and flowers are cultivated commercially. Here and there small patches of soil are used by locals for mostly personal use. Aruba is to such an extent different from the Netherlands that none of the Dutch equilibrium models apply. 


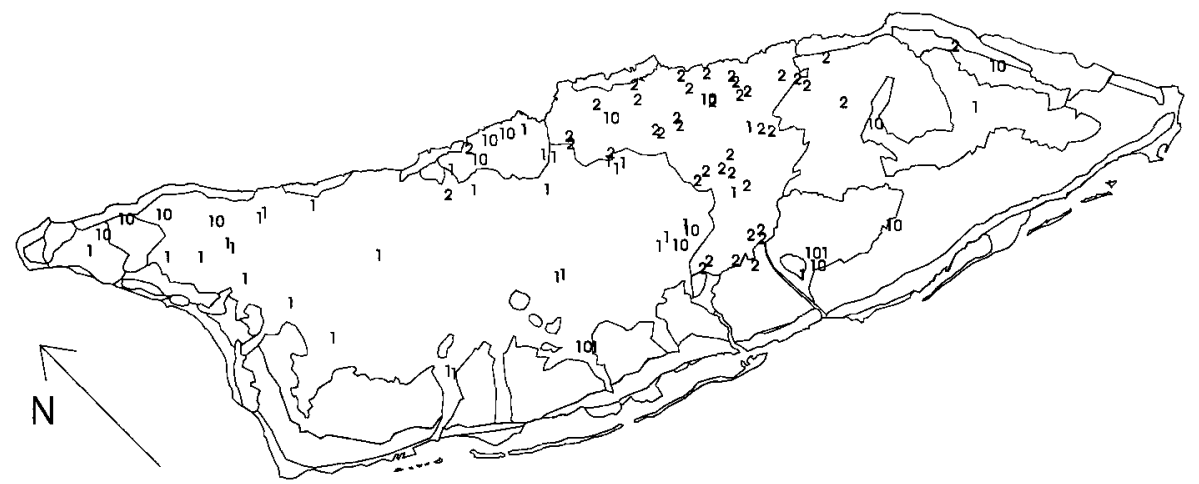

Fig. 6. Geographical distribution of the clusters of the 2-cluster model.

Because of the differences in geology, the metal concentration differs from place to place. One average could be taken for the whole island, or the island could be divided in different regions. The question is how to establish natural background values, or reference values. Uniform reference values per element are not well made consistent with the geological situation. As was shown above, the geological differences give rise to significant differences in element concentration. The FCM and NLM results for the 6-cluster model proved useful to explain the variation encountered in the data set. For the purpose of defining the reference value, the model is, however, possibly overly detailed. It appears that a 2-cluster model is sufficiently representative and practical for the implementation.

Table 4. Cluster centres of the two cluster model. The assigned names are tentative and indicate the main characteristic of the cluster. The 90 percentile values are based on the hard or crisp clusters (see text).

\begin{tabular}{|c|c|c|c|c|}
\hline & cluster ce & & 90 percer & \\
\hline & $Q D$ & $A L F$ & $Q D$ & $A L F$ \\
\hline majo & & & & \\
\hline $\mathrm{Al}$ & 2.27 & 3.67 & 3.13 & 5.00 \\
\hline $\mathrm{Fe}$ & 3.51 & 5.16 & 5.55 & 6.81 \\
\hline $\mathrm{Ca}$ & 1.35 & 2.02 & 2.09 & 3.76 \\
\hline $\mathrm{Mg}$ & 0.72 & 1.66 & 1.25 & 2.86 \\
\hline $\mathrm{Na}$ & 0.12 & 0.18 & 0.29 & 0.47 \\
\hline $\mathrm{K}$ & 0.23 & 0.30 & 0.39 & 0.47 \\
\hline mino & & & & \\
\hline $\mathrm{Ba}$ & 74 & 42 & 146 & 115 \\
\hline Co & 13 & 30 & 21 & 48 \\
\hline $\mathrm{Cr}$ & 49 & 160 & 192 & 365 \\
\hline $\mathrm{Cu}$ & 49 & 108 & 77 & 156 \\
\hline $\mathrm{Li}$ & 5.6 & 8.8 & 11.3 & 16 \\
\hline $\mathrm{Mn}$ & 535 & 870 & 685 & 1280 \\
\hline $\mathrm{Ni}$ & 18 & 59 & 32 & 126 \\
\hline$P$ & 325 & 350 & 795 & 785 \\
\hline S & 138 & 199 & 517 & 1125 \\
\hline $\mathrm{Sr}$ & 87 & 80 & 130 & 121 \\
\hline $\mathrm{Ti}$ & 1860 & 2705 & 3035 & 3600 \\
\hline V & 137 & 198 & 300 & 250 \\
\hline $\mathrm{Y}$ & 7.6 & 11.3 & 10.0 & 16 \\
\hline $\mathrm{Zn}$ & 37 & 56 & 64 & 80 \\
\hline $\mathrm{Zr}$ & 1.8 & 3.4 & 3.5 & 7.9 \\
\hline
\end{tabular}

It divides the island in two major parts, which tentatively could be named as the QD area and the ALF area (see Fig. 6). The cluster centres are given in Table 4. The ALF cluster has significant higher concentrations of metals, owing to the geology. Since lutum and humus content are not as important as in most other geological/pedological settings (such as in the Netherlands), they are not useful criteria for Aruba. The cluster centres listed in Table 4 can be considered as the averaged natural background values. The 90 percentile values of the hard or crisped clusters were calculated as well (Table 4) and may serve as an indication for the limit of the natural variation. When concentrations above these values are found for the base metals, more detailed investigations are warranted.

\section{Conclusions}

A geochemical baseline study for the island of Aruba, one of the Dutch Leeward Islands of the Lesser Antilles, was carried out. Through fuzzy c-means clustering and non-linear mapping, it is shown that the geology has the most noticeable influence on the sampled stream sediments. Concentrations in stream sediments represent the abundance of chemical elements in the drainage basins. For the definition of reference values for the soils, the island is best split in two parts with each their separate set of values. Basically these are related to the quartz-diorite and the Aruba Lava Formation.

\section{Acknowledgements}

The assistance of the Department of Agriculture, Fishery \& Cattle farming (DLVV), especially of Mr. T. Barnes, was greatly appreciated during our stay on the island. R.Ypenburg and R. Harms are thanked for logistic support and providing facilities. The support from S.P. Vriend, H. de Wijs and G. Ypenburg during the fieldwork and interpretation was of considerable help. 


\section{References}

Beeson, R., 1984. The use of fine fractions of stream sediments in geochemical exploration in arid and semi-arid terrains. Journal of Geochemical Exploration 22: 119-132.

Beets, D.J., \& MacGillavry, H.J., 1977. Outline of the Cretaceous and Early Tertiary history of Curaçao, Bonaire and Aruba. In: Guide to the field excursions on Curaçao, Bonaire and Aruba. GUA Papers of Geology (series 1) 10: 1-6.

Bezdek, J.C., Ehrlich, R. \& Full, W., 1984. FCM: the fuzzy c-means clustering algorithm. Computers \& Geosciences 10: 191-203.

Björklund, A. \& Gustavsson, N., 1987. Visualisation of geochemical data on maps: new options. Journal of Geochemical Exploration 29: 89-103.

Broecker, W.S. \& Peng, T., 1982. Tracers in the sea. Palisades (New York): $690 \mathrm{pp}$.

Chao, T.T. \& Sanzaolone, R.F., 1992. Decomposition techniques. Journal of Geochemical Exploration 44: 65-106

Chork, C.Y. \& Govett, G.J.S., 1985. Comparison of interpretations of geochemical soil data by some multivariate statistical methods, Key Anacon, NB, Canada. Journal of Geochemical Exploration 23: 213-242.

Cox, K.G., Bell, J.D. \& Pankhurst, R.J., 1979. The interpretation of igneous rocks. George Allen \& Unwin (London): 450 pp.

Darnley, A.G., 1990. International geochemical mapping: a new global project. Journal of Geochemical Exploration 39: 1-13.

Darnley, A.G., Björklund, A., Bølviken, B., Gustavsson, N., Koval, P.V., Plant, J.A., Steenfelt, A., Tauchid, M. \& Xie Xuejing, 1995. A global geochemical database for environmental and resource management. Earth Science (UNESCO Publishing) 19:122 pp.

Davis, J.C., 1986. Statistics and data analysis in geology $\left(2^{\text {nd }} \mathrm{ed}\right.$.). John Wiley \& Sons (London): $646 \mathrm{pp}$.

De Buisonjé, P.H., 1974. Neogene and Quaternary geology of Aruba, Curaçao and Bonaire. Natuurwetenschappelijke Studiekring voor Suriname en de Nederlandse Antillen (Utrecht) 78: $293 \mathrm{pp}$.

Deer, W.A., Howie, R.A. \& Zussman, J., 1992. An introduction to the rock forming minerals. John Wiley \& Sons (London): $696 \mathrm{pp}$.

Donnelly, T. \& Rogers, J.J.W., 1978. The distribution of igneous rock suites throughout the Caribbean. Geologie en Mijnbouw 57: 151-162.

Frapporti, G., Vriend, S.P. \& Van Gaans, P.F.M., 1993. Geochemi$\mathrm{cal}$ and statistical interpretation of a ground water monitoring network, province of Zuid Holland. $\mathrm{H}_{2} \mathrm{O} 9: 237-244$.

Hawkes, H.E., 1976. The downstream dilution of stream sediment anomalies. Journal of Geochemical Exploration 6: 345-358.

Helmers, H., 1977. The hooibergites of Aruba, a preliminary note. Abstracts of the $8^{\text {th }}$ Caribbean Geological Conference ( $\mathrm{Cu}$ raçao): $70-71$
Helmers, H. \& Beets, D.J., 1977. Geology of the Cretaceous of Aruba. Abstracts of the $8^{\text {th }}$ Caribbean Geological Conference (Curaçao): 29-35.

Herweijer, J.P. \& Focke, J.W., 1978. Late Pleistocene depositional and denundational history of Aruba, Bonaire and Curaçao. Geologie en Mijnbouw 57: 177-187.

Howarth, R.J., 1984. Statistical applications in geochemical prospecting: a survey of recent developments. Journal of Geochemical Exploration 21: 41-61.

Jarvis, E. \& Jarvis, K.E., 1992. Inductively coupled plasma-atomic emission spectrometry in exploration geochemistry. Journal of Geochemical Exploration 44: 139-200.

Kürzl, H., 1988. Exploratory data analysis: recent advances for the interpretation of geochemical data. Journal of Geochemical Exploration 30: 309-322.

Monen, H.P., 1980. The Aruba Lava Formation. Unpublished M.Sc. thesis Universiteit Amsterdam: 43 pp.

O'Conner, P.J. \& Reimann, C., 1993. Multi-element regional geochemical reconnaissance as an aid to target selection in Irish Caledonian terrains. Journal of Geochemical Exploration 47: 63-87.

Plant, J.A., Hale, M. \& Ridgway, J., 1988. Developments in regional geochemistry for mineral exploration. Transactions of the Institute of Mining Metallurgy 97: B1 16-B139.

Priem, H.N.A., Beets, D.J., Boelrijk, N.A.I.M. \& Hebeda, E.H., 1986. On the age of the Late Cretaceous tonalitic/gabbroic batholite on Aruba, Southern Caribbean borderland. Geologie en Mijnbouw 65: 247-256.

Reid, J.C., 1993. A geochemical atlas of North Carolina, USA. Journal of Geochemical Exploration 47: 11-27.

Steenfelt, A., 1987. Geochemical mapping and prospecting in Greenland - a review of results and experience. Journal of Geochemical Exploration 29: 183-203.

Van den Oever, F., 1993. Unpublished M. Sc. thesis Utrecht University.

Vriend, S.P., Van Gaans, P.F.M., Middelburg, J. \& De Nijs, A., 1988. The application of fuzzy c-means cluster analysis and non-linear mapping to geochemical datasets: examples from Portugal. Applied Geochemistry 3: 213-224.

Webb, J.S. (ed.), 1978. The Wolfson geochemical atlas of England and Wales. Clarendon Press (Oxford): $69 \mathrm{pp}$.

Westermann, J.H., 1932. The geology of Aruba. Geographische en Geologische Mededeelingen, Physiographisch-Geologische Reeks 7: 129 pp..

Wilson, M., 1989. Igneous petrogenesis, a global tectonic approach. Unwin Hyman (London): 466 pp.

Yu, B. \& Xie, X., 1985. Fuzzy cluster analysis in geochemical exploration. Journal of Geochemical Exploration 23: 281-291. 